This is an Accepted Manuscript of the article Villamayor-Tomas, S., Thiel, A., Amblard, L., Zikos, D., \& Blanco, E. (2019). Diagnosing the role of the state for local collective action: Types of action situations and policy instruments. Environmental Science \& Policy, 97, 44-57, available online at https://doi.org/10.1016/i.envsci.2019.03.009 @2019. This manuscript version is made available under the CCBY-NC-ND 4.0 license

\title{
Diagnosing the role of the state for local collective action: types of action situations and policy instruments
}

Sergio Villamayor-Tomas ${ }^{\mathrm{a}, *}$, Andreas Thiel $^{\mathrm{b}, \mathrm{c}}$, Laurence Amblard ${ }^{\mathrm{d}}$, Dimitrios Zikos ${ }^{\mathrm{e}}$, Ester Blanco $^{\mathrm{f}}$

${ }^{a}$ Institute of Environmental Science and Technology, Autonomous University of Barcelona, 08193, Cerdanyola del Vallès, Barcelona, Spain

${ }^{\mathrm{b}}$ Käte Hamburger Kolleg Centre for Global Cooperation Research, Duisburg University, Schifferstraße 44, 47059 Duisburg, Germany

${ }^{\mathrm{c}}$ International Agricultural Policy and Environmental Governance, University of Kassel, Steinstr. 19, 37213, Witzenhausen

${ }^{\mathrm{d}}$ Université Clermont Auvergne, AgroParisTech, INRA, Irstea, Vetagro Sup, Territoires, F-63000 Clermont-Ferrand, France

${ }^{\mathrm{e}}$ Humboldt Universität zu Berlin, Department of Agricultural Economics, Resource Economics Group, Unter den Linden 6, 10099 Berlin

${ }^{\mathrm{f}}$ Department of Public Finance, University of Innsbruck, Universitaetstrasse 15, 6020, Innsbruck, Austria

*corresponding author.sergio.villamayor@uab.cat

\begin{abstract}
This paper presents a diagnostic approach to the role and capacity of governments to facilitate local collective action and alleviate environmental problems. The paper adds to a nascent scholarship aiming to conciliate theories on "governance by government" and "governance by self-organization". We adopt two premises for that purpose: (1) policy instruments shall be tailored to the strategic nature of local resource management decisions; and (2) such nature is not static and can be modified via governmental policies. We first build on the Institutional Analysis and Development (IAD) framework to characterize the decisionmaking situations that local resource users face and the local rules that shape said situations. Then, based on common pool resource (CPR) and policy instrument choice theory, we identify four mechanisms through which different policy instruments can facilitate local collective action (change in payoffs and their perception, reduction of transaction costs, reduction of uncertainty, and normative consonance). This analytical approach is then applied to four illustrative cases of water management in Germany, France, Greece and Spain. As shown, local resource users are embedded in not one but many overlapping decision-making situations. In this context, the promotion of collective action is rarely accomplished via a single policy instrument or mechanism but via bundles of them. Also, the paper illustrates the importance of understanding how governmental policies modify the structure of rules and incentives that affect local resource users, potentially facilitating local collective action and the solution of environmental problems.
\end{abstract}

Key words: collective action; action situation; IAD framework; policy instruments; water management; Europe 


\section{Introduction}

In the last decades, the scope of governance alternatives for natural resource management has increased substantially. Traditionally, private property and state management were considered as the two only governance options likely to foster the sustainable management of commonpool resources (Hardin 1968). Over the 80s and 90s, growing evidence showed that users of natural resources could also self-organize for the management of resources. Those experiences constituted the base of a (new) common pool resource (CPR) theory (Ostrom 1990, Poteete et al. 2010) and a general recognition of the benefits of local collective action. Numerous decentralized policies, co-management arrangements, participatory decision making experiences and community-based conservation mechanisms have built since then on such understanding (Berkes 2004, Ansell and Gash 2008).

Local collective action, however, should not be seen as an environmental governance panacea, nor as an alternative to market institutions or the government. Despite the current momentum of local collective management experiences, public administrations including national, regional, local governments and sometimes supranational regulations still have a great deal of influence over the management of natural resources. For once, governments often back up property regimes with formal monitoring and sanctioning mechanisms based on the state's administrative capacities and coercive powers (Ostrom and Cox 2010). More importantly, governments may also play an important role in the facilitation and promotion of collective action experiences (Lemos and Agrawal 2006, Mansbridge 2014). A good example in point is the practice and study of Payment for Ecosystem Services (PES). Although originally conceived as a pure market instrument where buyers and sellers transact ecosystem services (Engel et al. 2008), PES have more recently been highlighted for their dependence on government and community-based organizations (and NGOs), as well as their potential to strengthen local cooperation (Muradian 2013, Sikor et al. 2017).

While a number of policy studies have theorized about the different instruments governments can use to solve environmental problems (Howlett 2004, Jordan et al. 2005, Goulder and Parry 2008), there is still rudimentary understanding about how policy instruments relate to local collective action situations and cooperation outcomes. The objective of this paper is to start filling that gap by exploring the extent to which different structures of incentives underlying an action situation warrant the use of different instruments.

We propose an analytical approach composed of two building blocks. Following Bowles (2009) and the Institutional Analysis and Development Framework (Ostrom et al. 1994), we pay attention to the different decision making situations (i.e, action situations) that local resource users experience and the rules that frame them. Additionally, we build on policy instrument choice theory to feature policy interventions according to the types of instruments used and mechanisms through which these interventions shall promote local collective action (Anthony and Campbell 2011). Ultimately, the goal is to test alignments between local action situations, policy instruments, and the collective behaviour of resource users, and by these means also explore how those instruments translate into specific rules.

Previous literature has formalized the interaction between policy instruments and specific action situations. For example, Bouma and Ansink (2013) analyse whether and how targeted payments for ecosystem services can extend the number of highly cooperative individuals in a larger community. Similarly, Zavalloni et al. (2016) analyse the combined use of incentives and minimum participation rules to enhance collective action. These studies model a specific policy intervention in a specific situation and generate detailed results on the interaction between the 
policy and the situation. Here, we trade depth for breadth and test our analytical approach against a selection of collective action experiences from the field of water management in the European Union.

Water management is one of the sectors where the governmental push for local collective action solutions has been most evident (Sabatier et al. 2005). In Europe, the Water Framework Directive and its emphasis on basin level management and participatory decision making processes is paradigmatic (Boeuf and Fritsch 2016). Other notable examples include a variety of local water pollution control experiences (Davies et al. 2004), and water conflict resolution mechanisms (Zikos and Hagedorn 2017). The empirical cases in this study were selected with the aim to capture diversity in management issues and settings in different countries. They include a German case of drainage management, a French case of water pollution control, a Spanish case of water conflict resolution, and a Greek case of participatory planning and management.

Section 2 presents the analytical approach linking types of action situations and policy interventions (i.e., instruments) based on contributions from CPR literature and policy instrument choice theory. This section also includes two conjectures about the relationship between situations and instruments. Section 3 describes the case study method used to apply the analytical approach and test the conjectures. Section 4 presents the results of applying the approach to the four cases of local collective action for water management. Section 5 synthesizes and compares the findings vis a vis the conjectures and the role of rules and analytical and methodological challenges.

\section{Analytical approach}

In this study we understand that local resource users are inclined to act jointly (in their own interest as a group and/or in the public interest) when they ultimately expect to improve their individual welfare that way (Scharpf 1997, Ostrom 1999a). Collective action from this perspective refers to the willingness and ability of resource users to coordinate their behavior in different degrees to realize both individual and group benefits (Ostrom 1990).

According to North (1988), the state, administered and steered by the government, trades a group of services, captured through concepts such as protection and justice and that way improves peoples' welfare in return for tax revenue. In modern, democratic societies, governments allegedly aim to conform to the desires of their principals, call it citizens, electoral constituencies, interest groups or even international conventions, in order to maintain order and legitimacy. Such motivation, which we equate in this paper to the public interest at large, may require the promotion of collective action at the local level.

According to the Institutional Analysis and Development Framework (IAD), local resource users interact in "action situations", which are situations where decisions by a group of individuals create outcomes that accrue to them or other groups (McGinnis 2011a). There are three sets of variables that shape action situations: resource characteristics, attributes of the community of resource users, and rules (Figure 1). In the water context (e.g., a river, an aquifer, an irrigation system), relevant resource characteristics believed to affect cooperation include the existence of infrastructure, the size of the system, or the predictability and productivity of the resource (Meinzen Dick 2007). Important attributes of the community comprise the size and heterogeneity of the user group and the existence of sufficient levels of trust among the users, to mention a few (Agrawal 2001). Rules are prescriptions about what individuals are allowed or obliged to do and potential sanctions in case of infraction. Different types of rules shape 
action situations (Ostrom 1999b, pp. 508): "Boundary rules affect the characteristics of participants. Position rules differentially affect the capabilities and responsibilities of those in positions. Choice rules affect the actions that participants in positions may, must or must not do. Scope rules affect the outcomes that are allowed, mandated or forbidden. Aggregation rules affect how individual actions are transformed into final outcomes. Information rules affect the kind of information present or absent in a situation. Payoff rules affect assigned costs and benefits to actions and outcomes" (see also Appendix 1.a and 1.b).

\section{Figure 1. The IAD framework}

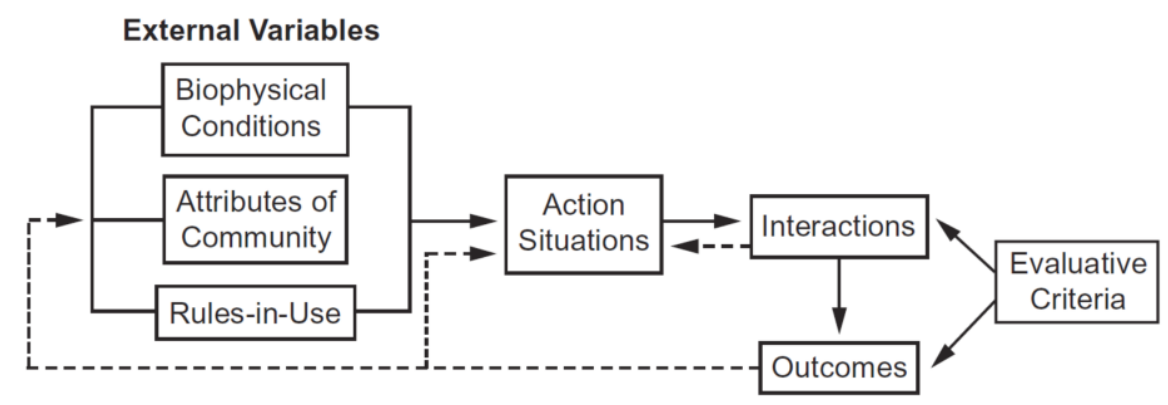

Source: Ostrom (2011)

Rules crafted by resource users are embedded in the legal and regulatory framework of local, regional and central government (Ostrom 2011). In this context, policy interventions (i.e., via policy instruments) can affect the rules shaping an action situation, with the intention to modify interactions and outcomes. Action situations will then move from "default" situations (i.e., the situation before the government intervention, where there are no rules or only basic rules for collective action), to institutionalized (or re-institutionalized) situations (Ostrom et al. 1994). From this perspective, government interventions are understood as interacting with local rules, community attributes and biophysical conditions in their impact on individual behavior (McGinnis 2011a). To assess these relationships, we propose an analytical approach that distinguishes between kinds of action situations on the one hand, and policy instruments on the other.

\subsection{Local users: types of action situations}

We argue that three types of action situations warrant government intervention to promote behavioural change by local resource users (Figure 2). 


\section{Figure 2. Types of action situations upon which governments shall intervene}

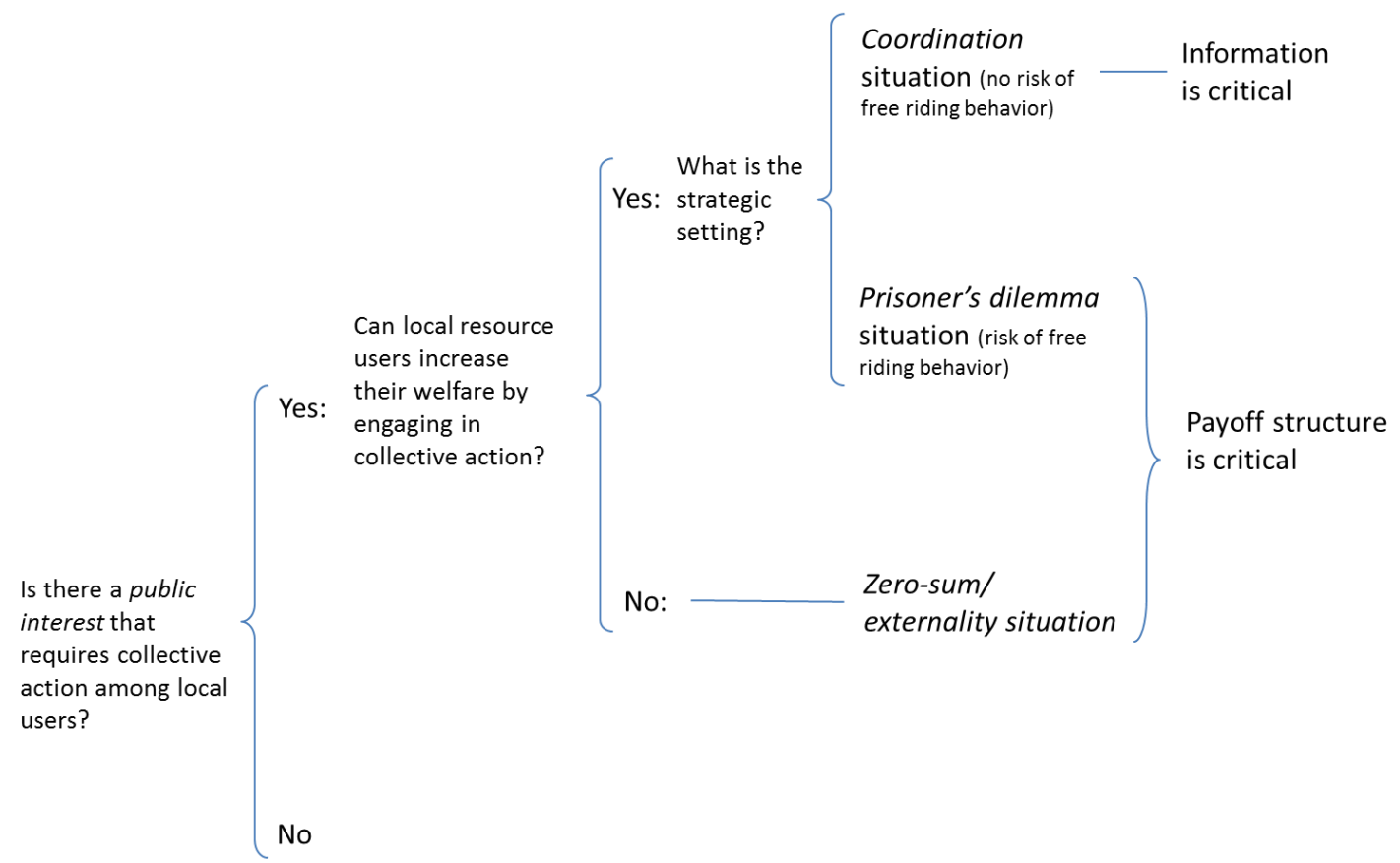

The first two types include settings uncovered in much of the common pool resource (CPR) theory where collective action entails an increase in the welfare of the group of local resource users and its fulfilment requires overcome collective action dilemmas (Aligica 2005, Poteete et al. 2010). Collective action dilemmas emerge when there is a conflict between individual and group benefits and are associated to the capacity of individuals to make strategic decisions (i.e., based on what others decide and the joint outcomes of those decisions). "If each individual selects strategies based on a calculus that maximizes short-term material benefits to self, individuals will take actions that generate lower joint outcomes than could have been achieved. ... such situations are called dilemmas [because].... At least one outcome yields higher returns for all participants, but rational participants making independent choices are not predicted to achieve this outcome." (Ostrom 2007, pp. 186). The existence of a social optimum that yields higher returns for all participants (i.e., local users) constitutes the essence of the collective action dilemma. Thus, any policy shaping these situations shall be assessed with regard to whether there is a pareto efficiency improvement in the payoffs (i.e., increase in benefits) of all the local users affected by the policy ${ }^{1}$.

CPR scholars have mostly focused on two situations that involve collective action dilemmas: coordination and prisoner's dilemma (Bowles 2009). In coordination situations, collective action is hindered by the lack of information or common understanding about the benefits of collective action and the expected behaviour of resource users. Users have an individual incentive to coordinate on strategies that entail higher outcomes; however, the transaction costs

\footnotetext{
${ }^{1}$ In this study, however, we are not testing government intervention vis-à-vis improvements in social optima but with regard to whether local users engage in collective action (see methods section). In the frame of mind of New Institutional Economics and game theory, local users would not engage in collective action if they did not expect their welfare to increase by that means. By the same token, government intervention is justified in the expectance of social welfare improvements.
} 
of obtaining information about others' strategies and building common understanding are considerable. Experimental evidence on coordination situations with standard populations shows that the capacity to communicate and share information, understandings or norms alleviates the coordination problem (Balliet 2010). Thus, one way to overcome the dilemma may therefore be that the government lowers transaction costs of communication, share information and ultimately coordination. A typical example is that of irrigation systems that are composed of many irrigation associations and/or distributed over large command areas. Even when the associations share an interest in joint management of water and infrastructure, the costs of collective decisions, for example, can be particularly high. Not without reason large, state-promoted irrigation systems have adopted a federal organizational structure whereby farmers in local systems elect leaders that represent them in decisions at larger scales (MeinzenDick 2007). Also, it may be necessary that a sufficient number of users coordinate (Kimmich 2013). Again, reaching such a threshold of participants may be facilitated if the government subsidizes coordination costs of a certain number of actors. Finally, an important characteristic of coordination situations is that punctual interventions can have long-lasting effects (Bowles 2009). This is because once an intervention induces agents to choose superior equilibrium strategies, no user benefits from deviating from the coordination equilibrium (Schelling 1980 calls this a focal point).

In prisoners' dilemma situations it is not the lack of information alone but rather a particular structure of incentives that leads to sub-optimal outcomes. Given a set of payoffs (i.e., costs and benefits), users have a dominant strategy to not cooperate and free-ride on the cooperation of others. In natural resource management contexts, such situation is represented by the classical "Tragedy of the Commons" (Hardin 1968), which illustrates the perverse incentives leading to resource degradation. A paradigmatic example in the water sector is that of groundwater in many regions around the world (Lopez-Gunn and Cortina 2006). The difficulties of monitoring water use constitute an important disincentive for farmers to restrain use, usually in contexts where water is already scarce. The transboundary nature of aquifers only aggravates the situation. That is the case of the divided island of Cyprus where two players (groups of Cypriot farmers from the North and South), with insufficient formalised communication channels and absence of any cross-border institutions or island-wide policies to regulate the use water, are competing for the resource in a sort of "race to depletion" and in the fear that their efforts to conserve ground water resources are jeopardized by the other party (Zikos and Roggero 2013, Zikos et al. 2015).

As shown by CPR scholars, cooperation in prisoner's dilemma situations can increase when communication is feasible. Communication allows agents to play reciprocal strategies or reach and abide by joint agreements or norms (Balliet 2010). By the same token, governments shall trigger or facilitate those efforts by changing the structure of payoffs, or the way users perceive them for example through framing particular choices (Anthony and Campbell 2011). Contrary to the coordination situation, however, the mere provision of information and communication in a prisoner's dilemma may not be enough to maintain cooperation, at least in the long term (Ostrom and Walker 1991, Lopez and Villamayor-Tomas 2017). Similarly, the effects of other policy interventions shall last only while the intervention is in place, unless resource users develop or comply with self-organizing rules and norms enforced for example through social pressure (Bowles 2009).

The third type of action situations includes settings where local users are not confronted with a collective action dilemma but with a conflict situation in the form of a zero-sum game. In zerosum game situations the wins of one side accrue at the expense of the losses of the other. These situations are not collective action dilemmas because there is not a "cooperative scenario" 
where the welfare increases for all users. Users may be acting in a coordinated fashion (e.g., as steered by the government) but they do not face the dilemma of acting in benefit of the group or not. Many of the conflicts around dam-building planning all over the world can be understood as zero-sum situations where the wins of downstream users associated to water storage and predictability are to a great extent mirrored by costs borne by the upstream communities whose lands are flooded (Villamayor-Tomas et al. 2016, Moran et al. 2018). Also, many local zerosum situations do not involve just local users but also the broader public (i.e., "outside users" at large). In these action situations, which we want to call externality situations, local resource users do not directly benefit from acting collectively even if the public at large does. Externalities do not significantly harm/benefit local resource users but "outsiders" of the local decision-making arena. Thus, there is, by default, no incentive for local users to change their behavior. This includes many of the environmental (positive and negative) externality situations uncovered in the environmental policy and economics scholarship (Stavins 2007), and typically portrayed in mobile pollution problems such as water pollution or acid rain(Walls and Palmer 2001).

There is a long tradition studying ways to cope with externality situations. The Coase theorem, stresses that these situations can be dealt with via deliberation processes among agents (when there are few numbers of agents) and side payments. In practical applications, however, Coase bargaining will rarely work satisfactorily because the preconditions are not met (no or low transaction costs, fully defined property rights, etc.). Thus, alternative types of solutions, i.e., government policies, are often called for (Bromley 1991). When groups of external beneficiaries can be identified, the government may try to facilitate transactions between beneficiaries and local resource users minimizing transaction costs that way. An example of this are Payment for Ecosystem Services (PES) programs in the water sector (de Lima et al. 2017). In cases where external beneficiaries are difficult to identify, governments may fund payments to local users on the basis of general tax revenues, impose rights via sanctions, or create right transfer systems (see cap-and-trade programs) (OECD 2013). Similar to the prisoner's dilemma situation, local resource users shall modify their behaviour if payoffs or perceptions of payoffs change, and the modified behaviour may endure only while the new payoffs or perceptions last (Grafton 2000).

\subsection{Government intervention: types of policy instruments}

The second piece of our analytical approach (i.e., in addition to the distinction of different action situations) is the featuring of government interventions. Based on policy instrument choice and CPR theory, we characterize government interventions based on the instruments used (see table $1)$.

One of the main contributions of policy instrument theory is the distinction of types of instruments. The literature in this regard is vast and ranges from the traditional classification of command-and-control instruments (pollution caps, licenses, resource use quotas) vs. economic instruments (taxes, subsidies, fees...) (Bemelmans-Videc et al. 2011), to more sophisticated typologies involving multiple dimensions and levels of analysis (Richards 2000, Lascoumes and Le Galès 2007, Howlett 2009). In a seminal contribution to the field, Christopher Hood (1986) argued that governments have essentially four means to affect citizen's behavior. In addition to their capacity to coerce (i.e., to command \& control) and to mobilize the "treasure" (i.e., via economic instruments like subsidies or taxes), governments can also use information (i.e., government reporting, advice, education programs) and organization (i.e., new organizations, enabling procedures, capacity building programs) (Howlett 2009). 
Hood's typology has notably influenced the policy instrument literature within CPR scholarship, which focuses on the tools that government can use to promote local collective action (Grafton 2000, Lubell et al. 2002, Koontz et al. 2004, Anthony and Campbell 2011, Mansbridge 2014). Despite its potential, the literature has progressed only partially. This may have to do with the traditional focus of CPR scholars on top-down, centralized natural resource management systems and their deficits (Acheson 2006, Cox 2016) and their relative ignorance of other means through which governments can have an impact on local resource management. Centralized systems do fail, but this does not mean that the capacity of governments to command-and-control is always ineffective or that governments cannot use other policy instruments. In a variety of situations, local polluting firms have recognized the presence of the state's "whip in the window" (i.e., in the form of standards or taxes) and chosen voluntarily to avoid it by organizing themselves into associations to self-regulate (Maxwell et al. 2000, Villamayor-Tomas et al. 2014). Additionally, governments can be supportive and facilitate cooperative behaviour via economic, organizational and information instruments (Grafton 2000), and also framing instruments (Anthony and Campbell 2011). Resource user groups may just lack the economic means to cover organizational set-up costs or collective resource use infrastructure that the government can provide (Koontz et al. 2004, Anthony and Campbell 2011). The promotion of river basin or groundwater organizations and collective irrigation infrastructure by the government in many countries around the world are paradigmatic examples here (Lopez-Gunn and Cortina 2006, Garces-Restrepo et al. 2007, Boeuf and Fritsch 2016). Also, sometimes resource users do not collaborate for lack of information, perspective and understanding of the benefits of it. The government here can not only provide the necessary information in a relatively neutral way via water monitoring systems (Mansbridge 2014) but also appropriate interpretation of the information to steer behaviour in a particular direction (i.e., framing), like in water efficiency and collaborative planning campaigns (Mckenzie 2000, Lubell 2003, Pavitt 2011).

\subsection{Mechanisms linking policy instruments and collective action across situations}

One way to link policy instruments and local collective action is looking at causal mechanisms behind collective action. Mechanisms can be broadly understood as "the processes and intervening variables through which causal or explanatory variables produce causal effects" (Bennett and George 1997, cited in Mahoney 2001). Much of CPR theory why some local user groups are able to engage in local collective action can be synthesized in a few mechanisms, including: a reduction of uncertainty (i.e. about the cooperative behaviour of others), a reduction of transaction costs (e.g. of collective decision making and monitoring), changes in pay-offs (i.e., the costs and benefits of acting collectively) and normative consonance (i.e., around payoffs shared goals) (Ostrom 1992, 2010, Cárdenas and Ostrom 2004, Poteete et al. 2010).

Preliminary evidence from the environmental policy field hints at some associations between types of policy instruments and collective action mechanisms (see Table 1). Governments can reduce uncertainty and transaction costs of local collective action via public information and monitoring instruments, or the organization of platforms for communication and collaborative planning among resource users (Kallis et al. 2006, Newig and Fritsch 2009, OECD 2013). For example, in a study of 76 government-sponsored watershed management partnerships in California and Washington, Leach and Sabatier (2003) found that that trust was important to catalyse collective agreements because it increased certainty about the success of cooperation. 
Table 1. Expected associations between policy instruments and action situations

\begin{tabular}{|c|c|c|}
\hline \multirow{2}{*}{ Types of policy instruments ${ }^{1}$} & \\
\hline & $\begin{array}{l}\text { Collective action } \\
\text { mechanisms }^{2}\end{array}$ & Action situations \\
\hline $\begin{array}{c}\text { Organization (e.g., introduction of participatory } \\
\text { planning, partnerships, management } \\
\text { organizations...) }\end{array}$ & \multirow{2}{*}{$\begin{array}{l}\text { Reduction of } \\
\text { transaction costs } \\
\text { Uncertainty reduction }\end{array}$} & \multirow[t]{2}{*}{ Coordination } \\
\hline $\begin{array}{l}\text { Information } \\
\text { (e.g., public information protocols, EIAs...) }\end{array}$ & & \\
\hline $\begin{array}{c}\text { Framing } \\
\text { (e.g., discourses, awareness raising campaigns) }\end{array}$ & \multirow{3}{*}{$\begin{array}{l}\text { Normative consonance } \\
\text { Change in pay-off } \\
\text { (and/or their } \\
\text { perceptions) }\end{array}$} & \multirow{3}{*}{$\begin{array}{l}\text { Prisoner's dilemma } \\
\text { Zero-sum/externality }\end{array}$} \\
\hline $\begin{array}{c}\text { Command-and-control } \\
\text { (e.g., environmental regulations, standards, } \\
\text { ITQs...) }\end{array}$ & & \\
\hline $\begin{array}{c}\text { Economic } \\
\text { (e.g., environmental taxes/subsidies, PES...) }\end{array}$ & & \\
\hline
\end{tabular}

${ }^{1}$ Based on Richards (2000), Lemos \& Agrawal (2006), Howlet (2009), Hood (1986); Howlett (2009) Anthony \& Campbell (2011) and Mansbridge (2014). Anthony and Campbell (2011) mention information to argue about the role the state has in changing perceptions about payoffs.

${ }^{2}$ Based on Ostrom (2006), Poteete et al. (2010)

Changes in payoffs can be accomplished via economic and command-and-control instruments, including for example the enforcement of environmental taxes, quality standards, quotas and conservation areas, or the implementation of infrastructure subsidies and payments for ecosystem services (Richards 2000, Lemos and Agrawal 2006, Jordan et al. 2010). In a study of the U.S. Environmental Protection Agency's WasteWise program, for example, Delmas \& Keller (2005) found that organizations joining the program were more likely to cooperate and report waste generation when there were benefits associated to such reporting.

Finally, normative consonance and changes in perceptions about payoffs can be promoted via appropriate framing instruments such as awareness raising campaigns, corporate social responsibility programs, and collective deliberation processes (Lubell 2003, Lund-Thomsen and Nadvi 2010). In a study of watershed management, for example, Lubell (2003) found that the collective-action beliefs (i.e., beliefs about net benefits of cooperation) of stakeholders involved in a participatory estuary management program were stronger than those of stakeholders in estuaries not involved in the program.

All the above paves the way to formulate some conjectures about associations between types of policy instruments and types of action situations. Specifically:

- We expect that problems profiling coordination situations tend to be resolved via policy instruments that reduce transaction costs and uncertainty (i.e., information and organizational instruments).

- We expect that collective action in prisoner's dilemma, and zero-sum/externality situations will tend to require instruments that change pay-offs and understandings (i.e., economic, command-and-control and framing instruments) in the long run. 
Last but not least, policy instruments do not operate in an institutional vacuum locally. They have an impact on behavior because they modify, create or contribute to implement rules that frame action situations (Ostrom et al. 1994). How they do so has largely been unaddressed in the literature. The IAD distinction of different types of rules facilitates a first exploration. In what follows we test the analytical approach and conjectures and explore associations with rules against a series of "most-different" cases of water management.

\section{Methods}

Cases were selected based on three common features, including the existence of an environmental problem, a local group of water users believed to contribute to the problem and its potential solution, and a policy intervention aiming at fostering collective action by users for solving the problem. The case studies differ in terms of the type of environmental problem and purpose of the government intervention, as well as the spatial scale and collective action outcomes. Collective action is measured through different proxies in the cases, including the ability of local users to self-organize and operate local collective management organizations (i.e., in the German and French cases, respectively), and the ability to collectively come to terms for conflict resolution, and planning (i.e., in the Greek and Spanish cases). Cases were documented by the authors on the basis of previous fieldwork and/or secondary sources such as technical papers, published case studies, Ph.D. theses or government reports to which the authors had access to (see Appendix 2 for details for each case). Special attention in the data collection was paid to the stylized characterization of the default local setting, the public interest pursued by government intervention, and the policy instruments through which such intervention materialized.

The analysis proceeded in two steps. First, we developed analytical narratives of the cases (Bates et al. 1998). This involved the identification of the group of local resource users and their interests, the motivation for the government to promote a change in the behaviour of users, and whether this was accomplished. Then, we reviewed the case through the proposed approach. This involved a characterization of the default action situation/s (i.e., before the intervention), an inventory of the policy instruments used by the government to promote change, the rules affected (see Appendix 1.b for details on the question used to assess the rules), and a reasoning about the mechanisms through which said instruments paved the way for collective action among the users. When possible, we traced the process of events that linked the government intervention and the change in behaviour by resource users (Collier 2011).

\section{Results}

In what follows we present the narratives of the four cases (see Table 2 for a summary). Appendix 3 contains also a detailed characterization of the situation before government intervention (i.e., "default") and the situation after as per the IAD components (resource and community characteristics, and rules). 
Table 2. Synthesis table of case analysis

\begin{tabular}{|c|c|c|c|c|c|}
\hline$\overbrace{\tilde{n}}^{\mathscr{W}}$ & Policy instruments & Affected rules ${ }^{1}$ & Mechanism & $\begin{array}{l}\text { Action } \\
\text { situation }\end{array}$ & 豙. \\
\hline \multirow{6}{*}{ 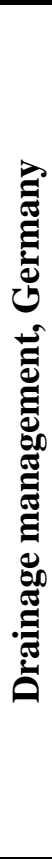 } & $\begin{array}{l}\text { (Organization) } \\
\text { Association: mission, collective } \\
\text { choice rules and } \\
\text { Agrarumweltforum }\end{array}$ & $\begin{array}{l}\text { Scope, } \\
\text { aggregation }\end{array}$ & $\begin{array}{l}\text { Reduction } \\
\text { transaction costs }\end{array}$ & Coordination & 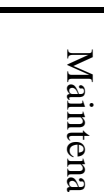 \\
\hline & $\begin{array}{l}\text { (Command-and-control) } \\
\text { Association: Mandatory } \\
\text { enrolment for municipalities -and } \\
\text { farmers- based on land registries }\end{array}$ & Boundary & Change in payoffs & \multirow{4}{*}{$\begin{array}{l}\text { Prisoner's } \\
\text { dilemma }\end{array}$} & \multirow{5}{*}{ 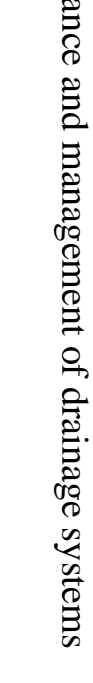 } \\
\hline & $\begin{array}{l}\text { (Organization) } \\
\text { Association: Mandatory fees paid } \\
\text { by municipalities also on behalf } \\
\text { of farmers }\end{array}$ & Payoff & Change in payoffs & & \\
\hline & $\begin{array}{l}\text { (Command-and-control) } \\
\text { Association: Municipalities are } \\
\text { responsible for monitoring }\end{array}$ & $\begin{array}{l}\text { Position, } \\
\text { information }\end{array}$ & $\begin{array}{l}\text { Reduction of } \\
\text { transaction costs \& } \\
\text { uncertainty }\end{array}$ & & \\
\hline & \begin{tabular}{|l|} 
Economic) \\
Infrastructure subsidies
\end{tabular} & Payoff & Change in payoffs & & \\
\hline & $\begin{array}{l}\text { (Economic) } \\
\text { Agri-environmental subsidies }\end{array}$ & Payoff & Changes in payoffs & Zero sum & \\
\hline \multirow{4}{*}{ 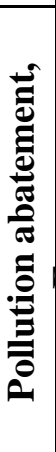 } & $\begin{array}{l}\text { (Organization) } \\
\text { Label organization: monitoring } \\
\text { system }\end{array}$ & $\begin{array}{l}\text { Information, pay- } \\
\text { off }\end{array}$ & \multirow[t]{2}{*}{ Change in payoffs } & \multirow{4}{*}{ Externality } & \multirow{4}{*}{ 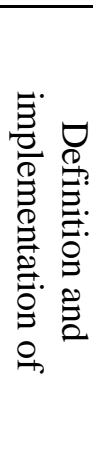 } \\
\hline & $\begin{array}{l}\text { (Command-and-control) } \\
\text { Threat of regulations }\end{array}$ & Payoff & & & \\
\hline & \begin{tabular}{|l|} 
(Organization $)$ \\
Ferti-mieux program organization
\end{tabular} & $\begin{array}{c}\text { Scope, position, } \\
\text { boundary, choice, } \\
\text { aggregation }\end{array}$ & \multirow[t]{2}{*}{$\begin{array}{l}\text { Reduction } \\
\text { transaction costs }\end{array}$} & & \\
\hline & \begin{tabular}{|l|} 
(Information) \\
Technical assistance \\
\end{tabular} & Information & & & \\
\hline \multirow{3}{*}{ 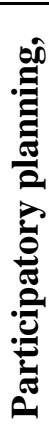 } & $\begin{array}{l}\text { (Organization) } \\
\text { Communication forum: rules for } \\
\text { roles within }\end{array}$ & Position, choice & $\begin{array}{c}\text { Reduction of } \\
\text { transaction costs \& } \\
\text { uncertainty }\end{array}$ & \multirow{2}{*}{$\begin{array}{l}\text { Prisoner's } \\
\text { dilemma }\end{array}$} & \multirow{3}{*}{ 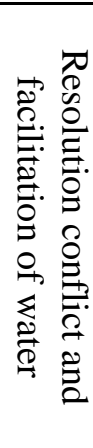 } \\
\hline & $\begin{array}{l}\text { (Command-and-control) } \\
\text { Governments endorse forum } \\
\text { decisions }\end{array}$ & Scope & Change in payoffs & & \\
\hline & $\begin{array}{l}\text { (Organization) } \\
\text { Communication forum: Protocol } \\
\text { for deliberation and decision } \\
\text { making }\end{array}$ & $\begin{array}{l}\text { Aggregation, } \\
\text { information }\end{array}$ & $\begin{array}{l}\text { Normative } \\
\text { consonance }\end{array}$ & Zero-sum & \\
\hline \multirow{2}{*}{ 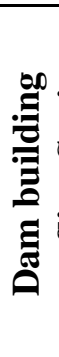 } & $\begin{array}{l}\text { (Organization) } \\
\text { Water Commission: mission, } \\
\text { rules for inclusion and roles } \\
\text { within }\end{array}$ & $\begin{array}{l}\text { Boundary, } \\
\text { position, choice, } \\
\text { scope }\end{array}$ & $\begin{array}{l}\text { Reduction of } \\
\text { transaction costs \& } \\
\text { Reduction of } \\
\text { uncertainty }\end{array}$ & & \multirow{2}{*}{ 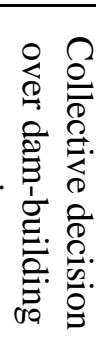 } \\
\hline & $\begin{array}{l}\text { (Organization) } \\
\text { Water Commission: Protocol for } \\
\text { deliberation and decision over } \\
\text { alternatives }\end{array}$ & $\begin{array}{l}\text { Information, } \\
\text { aggregation }\end{array}$ & $\begin{array}{l}\text { Normative } \\
\text { consonance }\end{array}$ & Zero-sum & \\
\hline
\end{tabular}




\begin{tabular}{|l|l|c|c|c|}
\hline $\begin{array}{l}\text { (Information) } \\
\text { Environmental Impact } \\
\text { Assessment }\end{array}$ & Scope & Change in payoffs & \\
\cline { 1 - 3 } $\begin{array}{l}\text { (Command-and-control) } \\
\text { Government ratifies decisions } \\
\text { from Commission }\end{array}$ & Scope & Change in payoffs & \\
\hline
\end{tabular}

${ }^{1}$ See Appendix 3 for details about the changes in rules before and after the government intervention.

Note: within each case, some policy instruments (see organization instruments in particular) have been disaggregated into different rows to highlight the separate effect of different components.

\subsection{Drainage maintenance, Germany}

The first case covers the successful intervention by the regional government in Schraden (the level of the Land), Brandenburg, Germany, in the period 1994 - 2005 to counterbalance the water quality, soil and ecosystem degradation produced by drainage management and the lack of maintenance of collective drainage infrastructure (Schleyer 2012).

This case is characterized by the existence of three overlapping situations among users (i.e., farmers, nature protection agencies, anglers, municipalities and other land and forest owners). First, for all users, the maintenance of drainage infrastructures represents a prisoners' dilemma as drainage is a local public good the provision of which faces incentives to free-ride. Second, operation of the drainage system faces both coordination and zero-sum situations. On the one hand, farmers are confronted with a coordination situation. They have similar interests regarding water tables, thus operation of the drainage system mostly requires that they coordinate on how to maintain the desired water table. On the other hand, farmers and other water users (i.e., municipalities, other landowners) have different interests regarding the level at which to maintain water tables. Farmers prefer maximal drainage to facilitate production, while some landowners and municipalities prefer higher water tables to maintain certain aquatic habitats. Here, users are embedded in a zero-sum situation, where satisfying the preferences of one type of user goes in detriment of the preferences of the other type. Accordingly, some are willing to financially contribute to drainage while others are not (Schleyer 2012).

The intervention of the government included several instruments. First, the government promoted the set-up of a "Kleine-Pulsnitz water association" with the mission of managing drainage (scope rules). This expectedly reduced transaction costs among farmers to come together; indirectly it affected or rather established information rules as the newly established forum facilitated information exchange. More importantly, an infrastructure maintenance subsidy program (payoff rule) was introduced and the municipalities became obligatory members that were charged on behalf of farmers. Subsequently, municipalities used their statutory rights to levy fees from farmers (new position and information rules). This changed the structure of payoffs making payments more likely. Also, mandatory membership fees charged to farmers (payoff rule) provided means for the association to invest in the maintenance of the drainage system. Municipalities also became responsible for monitoring the compliance of farmers with management plans within their jurisdictions (position and information rules), thus reducing the uncertainty associated to non-compliance at relatively low cost (i.e., as compared to direct monitoring by the central government or the set-up of a farmer-to-farmer monitoring). This minimized free riding behaviour by farmers. Joint planning was further facilitated by a group of researchers that created a temporary roundtable for agri-enviromental affairs in the area (Agrarumweltforum), as well as by planning processes steered by the Nature Protection Agency and attended by the municipalities on behalf of farmers (aggregation rules). 
This contributed to reduce the transactions costs of bargaining for local users. The purpose of bargaining was to find solutions that maximize benefits of local users (i.e., benefits resulting from mutual adjustment for drainage management). It is unclear whether the communication process itself contributed to said adjustment (i.e., beyond reducing the transaction costs of it). Agri-environmental subsidies (pay-off rules rewarding the alignment of farmer's interests and management choice to those of municipalities) seem to have played a stronger role in that regard. In result, the status of maintenance of the drainage system was improved but, as the study also shows, further deficiencies remained. Responsible for continuing problems that the study diagnosed were sometimes stark differences in interests among farmers, mainly because of differences in farm size. Very large farmers were able to adapt by themselves sidelining the role of drainage management. Further, for a long period, collective action at the local level was weakened by the fact that it was not embedded into higher scale coordination through land and water use planning (Schleyer, 2012).

\subsection{Pollution control, France}

The second case corresponds to a problem of agricultural water pollution in France and the implementation of the Ferti-Mieux program (1991-2002 country-wide, and to date in RhinMeuse water basin), i.e., a governmental program with the goal to coordinate and label local collective actions of farmers for a better management of nitrogen use at a water-catchment level (Papy and Torre 2002).

This case can be understood as an externality situation. Like in similar upstream-downstream pollution contexts, polluters (here farmers) have little incentive for reducing the level of pollution or contributing to the maintenance of water quality downstream (Villamayor-Tomas et al. 2014). Changes in farming practices may be costly and farmers do not generally draw direct economic benefits from reducing water pollution as these mostly materialize downstream.

The creation of a labelling system by the government provided marketing benefits for farmers in exchange of reducing the use of fertilizer (i.e., payoff rule). The participation of farmers was also triggered by the threat of regulatory intervention if the objectives of pollution control were not met (payoff rule). This constituted an incentive for farmers to join the system. The government intervention put farmers in a prisoner's dilemma situation, where the efforts of some could be jeopardized by the free-riding behaviour of others. To avoid this, a monitoring system was established based on direct controls of farms by a local technical committee (information rule). By creating a basic local organizational structure with a mission (scope rules), pre-designed roles (i.e., position rules: steering committee, coordinator...), membership (boundary rules) and procedures to co-design the Nitrogen Management Plans (aggregation rules), the government also lowered transaction costs associated to coordination among farmers. Finally, information costs regarding changes in agricultural practices were reduced via a technical assistance program (information rule) for farmers.

Between 1991 and 2001, 65 operations were labeled, involving about 35,000 farmers and representing $4.6 \%$ of the agricultural area (Verron, 2007). The effects of the "Ferti-Mieux" operations on water pollution were mixed, with no evidence of decrease in nitrate rates in groundwater bodies; however, one explanation could be the inertia of hydrologic processes in groundwater systems. In areas where surface waters were targeted, more than a half of the operations led to a decrease or a stabilization of nitrate rates (Papy and Torre, 2002).

Governmental support was crucial in this case, as illustrated by the fact that most operations collapsed after the official stop of the policy at the national level, except for the operations in 
the Rhin-Meuse water basin area, where the Water Agency decided to take over the support of the Ferti-Mieux program at the water basin level. Indeed, the on-going "Ferti-Mieux" operations in the area were evaluated as successful, in terms of farmers' involvement and water quality improvement (Bernard 2004).

\subsection{Participatory decision-making Greece}

The third case covers the implementation by the local government and a European research project of an informal forum for information exchange and deliberation in the metropolitan area of Volos, within the Pinios basin, Greece (2004-2006). The forum, which addressed previously failed attempts at participatory watershed planning and conflicts between water users (farmers, urban users) in the basin, paved the way for further planning efforts (Dimadama and Zikos 2010).In this case several action situations overlapped. First, water users were confronted with a coordination situation, i.e. one where transaction costs prevented the identification of winwin planning measures. However, the coordination situation was superseded by two circumstances. First, contradicting interests of stakeholders (protection of water resources vs. increased supply, allocation of water for different uses and tariff policies to mention a few) had escalated into conflicts, ending up at the courtroom. Thus, water users found themselves in a zero-sum situation where satisfying the interests of one player resulted in direct losses for the other. Third, stakeholders were trapped in a situations that echoes a prisoner's dilemma. In the absence of communication and because of actors' fears of being the only party giving in to the other's interests, the stakeholders pursued their own utility maximisation related to water planning and water projects despite the potential gains from cooperation (Zikos and Thiel 2013).

The financing and organization of a series of deliberative meetings within the framework of a research project set the basis for low cost communication among stakeholders. The scope of the experience was similar to that of the failed participatory water planning process; however, local users played a different role, i.e., one of equals as part of a relatively open research process (new position and choice rule). Furthermore, expected opportunity costs of non-participation increased due to the commitment by both the local government and the water utility to endorse the forum outcomes. In this sense, scope for joint decisions, was considerably larger than under the old participatory process (new scope rule). Also, the prospect of influencing directly regional water policies and indirectly national policies through the implementation of a River Basin Pilot project in the region, provided incentives for actors to maintain meaningful discussion and exchange beyond the period of existence of the forum itself. Moreover, the provision of collective and choice rules that deliberation turned from a finite set of fora meetings into an infinite sequence of negotiations facilitated the disciplining effect of potential for titfor-tat strategies through these consecutive, ongoing negotiations. This new constellation facilitated the resolution of conflicts outside courts. Perceptions of stakeholders were changed in a way that made it too "costly" for any actor involved to drop out from participating in the meetings. Although the network ceased to exit after the researchers pulled-out from their facilitating role, the established cooperative structures and collective decision-making culture survived. This resulted in the continuous, amicable resolution of conflicts between actors persisting until today but it also facilitated water related policy decisions that had been recognised as vital for the water future of the region (Zikos 2010). 


\subsection{Dam building conflict resolution, Spain}

The fourth case revolves around the conflict that emerged between upstream communities and downstream irrigators over a dam-building project in the Matarraña watershed in Aragon, Spain (1997-2005). To solve the conflict and avoid future conflicts over dam-building, the regional government created a multi-stakeholder platform under its tutelage, i.e., the "Water Commission".

The conflict had put in evidence a zero-sum situation, where environmental benefits and costs (i.e., of a big infrastructure project) were distributed in a way that caused clear winners and losers, and where compensation to local communities was not an option for the communities. The conflict had created a stalemate that did not benefit the general public nor the local users (Casajús Murillo et al. 2012).

The Water Commission organization was created with a mission (scope rule) and a basic set of rules about who would participate and in which role and decision capacity (boundary, position and choice rules). All this lowered the transaction costs of getting the stakeholders together. This was key in the process, as nor the parties or the central government via its Water Agency, had shown any ability to facilitate such process. The group of users participating in the Commission had ample discretion to explore alternatives to the original dam building project (scope rule); the central government would accept whatever decision would come out of the process. This added credibility to the process and increased the opportunity costs of not participating in it (Celaya 2006). Farmers initially benefited from considerable lobbying power over the central government (the initial project had been designed to satisfy their interests); however, an unfavourable Environmental Impact Assessment of the project confirmed that the kind of big public works that the project represented were not a possibility (new scope rule), and balanced farmers' power in favour of the upstream communities, which facilitated bargaining (Monge and Presa 2011). Also, the Commission was created with a basic set of rules to deliberate and make decisions (aggregation rules). This not facilitated the collective bargaining (Monge and Presa 2011) and ultimately also the generation of sufficient common understanding and trust among the parties so each was willing to give up to some of their claims (Casajús Murillo et al. 2012). In 2005 the stakeholders in the Water Commission reached a collective agreement to replace the original project with a project consisting of the construction of a series of smaller reservoirs in different locations of the basin and contiguous basins. Two of the pools have been constructed and in operation (Casajús Murillo et al. 2012).

\section{Discussion}

The analysis of the cases yields a number of discussion points. Some of them speak about insights gained through the analytical approach, the validity of our conjectures and policy implications. A number of other insights uncover challenges and ways to move forward.

\subsection{A diversity of action situations and policy instruments; a one to one relationship?}

Overall, the cases display different degrees of complexity, as measured by the types of action situations that local user groups face, and the number and diversity of policy instruments used by the governments to steer their behaviour. 
As per our knowledge of the cases, the German drainage case displays the highest degree of complexity. Users are embedded in three overlapping situations that require collective action. One of them is related to the maintenance of shared infrastructure (prisoner's dilemma) and the two others are associated with the coordinated management of the infrastructure (a coordination or zero-sum situation depending on the configuration of local actors). Contrasting with the German drainage case is the Spanish dam building conflict case, which is featured by a single zero-sum situation. Although the German and Spanish and Greek cases all feature a zero-sum situation, the German and Greek cases involves also other action situations which makes them less comparable to the Spanish case. In the German case, the zero-sum situation is only indirectly related to the management problem, i.e. solving conflicts about drainage operations is secondary to first self-organizing to invest in infrastructure maintenance and the drainage management protocol. The Greek case is similar to the German case in that the solution of the zero-sum situation first requires overcoming the prisoner's dilemma that prevents users to get together in the first place. Alternatively, in the Spanish case, the zero-sum situation is core to the problem at stake.

Everything being equal, the existence of interacting action situations makes problems more difficult to diagnose and policy less predictable than otherwise as one has to take into account how policy interventions, in one situation affect adjacent situations (McGinnis 2011b). In a study of water-energy use interactions in India and Spain, for example, Kimmich and Villamayor-Tomas (2017) show how policy interventions aiming to make irrigation associations less vulnerable to droughts and more prone to irrigation development resulted in issues of energy use sustainability, respectively. By the same token, in the German case, policies focusing only on resolving the coordination situation among farmers (i.e., via drainage plans that ignore the interests of municipalities and other users) could have aggravated the zero-sum problem situation that confronts farmers and the other users. The French case is also revealing in this regard. Initially, farmers did not face any collective action dilemma (externality situation); however, they were confronted with a prisoner's dilemma once the government pushed for abating nitrogen pollution. A government intervention aiming only at making farmers reduce nitrogen use without recognizing the prisoner's dilemma the farmers face to do so would have undergone serious effectiveness issues.

Also, in none of the cases the emergence of collective action can be explained by a single policy instrument. Indeed, all cases display bundles of instruments, ranging from the combination of mostly organizational instruments (communication forum and collective choice rules) in the Greek case, to the combination of organizational, economic and command-and-control instruments (decision making fora, collective choice rules, funding for monitoring and infrastructure, enforcement, and subsidies) in the German case. This illustrates the interest of assessing environmental policy instruments from a configurational perspective rather than understanding them as alternatives (Bemelmans-Videc et al. 2011).

We did not find evidence of the use of framing instruments in any of the cases. We believe this has to do with data limitations rather than with the actual lack of relevance of this type of instruments. Framing has been shown to be a powerful governance instrument in the hands of governments (Schneider and Ingram 1993, Hajer and Laws 2010). To some extent, framing is ubiquitous in governmental action. The mere definition of problems, attribution of causes and proposal of solutions is an exercise of framing (Gusfield 1981). For example, in the French case, the Ferti-Mieux program enhanced the understanding of nitrogen pollution as a problem caused by local farmers. Thus, the intervention was steered to encourage farmers to do something about it. Also, recognizing the constructed nature of environmental problems and associated action situations is important (Lubell 2003, Anderies et al. 2011). The Greek case is 
illustrative here; although in essence users were confronted with a zero-sum situation associated to the water planning controversy, they also perceived the situation as involving a prisoner's dilemma whereby the fear of being the only part giving in prevented them from engaging in more constructive approaches to decision-making.

A more detailed look at action situations and instruments sheds some light on the validity of our conjectures. In almost all instances we observe an alignment between the use of economic and/or command-and-control instruments on the one hand and the existence of a prisoner's dilemma and/or a zero-sum/externality situation. This provides support our second conjecture about the relationship between said types of action situations and policy instruments. Importantly, the cases indicate that economic and command-and-control instruments alone are not sufficient to promote local collective action. In all cases, including also those uniquely profiled by a zero-sum/externality situation (French and Spanish cases), those instruments were complemented with organizational or informational instruments. In other words, organizational and informational instruments were not exclusively associated to coordination situations, which goes against our first conjecture. The pervasiveness of these types of instruments is not totally counterintuitive as they contribute to reduce transaction costs and uncertainty about the effectiveness of collective action. This points to the outstanding relevance of transaction costs in collective action theory (Williamson 1981, McGinnis 2005), and the importance to balance the costs and benefits of collective action (Ostrom 1990).

Finally, the findings also prove the existence of a many-to-one relationship between policy instruments and action situations. As illustrated particularly in the French and Spanish cases but also in the other cases, action situations are addressed by several instruments simultaneously. This is not trivial given that much of the policy tool literature has assumed a one to one relationship between instruments and problem situations, and rather ignored the potential or even need to use multiple instruments to promote a particular collective behaviour (Howlett, 2004).

\subsection{The provision of rules for collective action}

The analysis also sheds light on how government intervention affects local collective action rules. In all the cases, the government intervention meant the creation of rules that structure self-organization by users (boundary, position, choice, aggregation and scope rules). This was mostly accomplished via organization and command-and-control instruments. In some cases, the rules filled an institutional gap. In the German case, the sponsoring of the Kleine-Pulsnitz water association by the government involved the creation of new rules that were previously inexistent, including new boundary rules (i.e., membership in the association), scope rules (water association as new local authority over drainage management outcomes and access and representation in negotiations over funds made available by higher level public authorities), and a redefinition of positions and choice options (see in particular the new role of municipalities). Similarly, in the French case, the Ferti-Mieux program provided for an institutional framework facilitating self-regulation by farmers vis à vis nitrogen control in a context marked by the initial disinterest of farmers to do something about pollution (i.e., externality situation). Alternatively, in the Greek and Spanish cases, the sponsorship of a local communication forum by the local government, overlaid existing institutions (see in particular position, choice and information rules), which were indeed at the origin of the stalemate.

Also, the impact of government on rules that structure self-organization takes place at different levels of action (Kiser and Ostrom 1982). First, the setting-up of new organizations like the Kleine-Pulsnitz water association or the Ferti-Mieux scheme is a "constitutional" act by which 
the government enables a space for collective decision and action by local users. The new boundary, position and choice rules for local users facilitated that farmers "come together" to address the problem. Second, by providing means for users to bargain and make decisions within those organizations (i.e., aggregation rules), the government was facilitating that farmers self-organize also at the collective choice level (i.e., to make collective decisions about how to manage the resource).

Although rules that structure self-organization are important, they do not seem to be sufficient. Stakeholders still needed to buy into and abide by the new rules. In this regard, the changes in the pay offs made by the government (mostly via command-and-control) also played a major role. In the German case, the obligation to enrol the association and pay membership fees and the implementation of pro-conservation subsidies paved the way for water users (particularly farmers) to buy into the new collaborative regime. The same can be argued about the threat of discretionary action by the government in both the Spanish and the French cases, and the incentive triggered by the governmental endorsement of local decisions in the Greek and Spanish cases.

A more fine-grained look at the relationship between rules and mechanisms reveals some unexpected alignments. Not all changes in the pay-offs (i.e., net benefits) of cooperation were the result of changes in pay-off rules (rules rewarding or sanctioning cooperative/ individualistic behavior). In the Spanish, and Greek cases, scope rules (i.e., endorsing local users' leverage to make collective decisions involved an important change in payoffs for users (i.e., an increase in the opportunity costs of not participating in the collective decisions and/or of not coming to agreements, respectively). Also, in the Spanish case, a change in a scope rule (i.e., the release of the Environmental Impact Assessment which restricted the original project and potentially also similar options) meant an important change in the costs of failing to reach an agreement for farmers. Finally, in the German case a boundary rule (i.e., obligatory membership of municipalities and farmers in the drainage association) meant an important change in the situation since the measure directly curtailed free riding behaviour (i.e., vis a vis participating in the organization of drainage). All these examples illustrate the interest of carrying further work on types of rules and their effects on collective action mechanisms (Poteete et al. 2010).

\section{3. “Governance by government" vs. "governance by self-organization"?}

The above results also question the traditional cleavage between theories of "governance by government" (such as policy instrument choice theory) and "governance by self-organization" (such as the theory of the commons). Lemos and Agrawal (2006) long pointed to the existence of a false trichotomy between governance by government, governance through markets and governance via self-organization and point to the existence of numerous hybrid arrangements such as government-led payment for ecosystem services, co-management and participatory decision-making programs, or cap-and-trade systems. Similarly, Driessen et al. (Driessen et al. 2012) theorize about the existence of different modes of governance depending on the dominance exerted by the government over civil society (self-organized groups) and markets and associate different actor, institutional and policy features (including instruments) to each mode. Our contribution builds on the above works and furthers it by looking at the strategic interactions between local resource users (i.e., the distinction between types of action situations), the local rules that shape individual behaviour and local collective action, and the instruments that governments use to promote such collective action. 
To be sure, our findings should not be understood as an argument in favour of delegating the promotion of local collective action and/or environmental governance entirely to governments. Although we have not included here cases of government intervention failure, the risks of such failure are significant, as already well-illustrated in the CPR literature (Acheson 2006). Those risks, on the other hand, should not prevent scholars from looking at the potential of governments and local communities to interact in mutually beneficial ways. The comanagement literature is unique in its focus on such interactions and the identification of the conditions under which "governance by government" and "governance by self-organization" can help each other (Koontz et al. 2004, Frey et al. 2016). As illustrated here, a complementary entry point is the study of the condition under which governments can promote selforganization.

\subsection{Analytical and methodological challenges}

In carrying this study, we confronted a few challenges that deserve to be mentioned here. Further research shall tackle them more systematically than done here. First, our analytical approach deliberately omits a public choice perspective (Mueller 1997), according to which governments and their representatives are heavily influenced by organizational survival and electoral competition dynamics. It is unclear in the French or Spanish cases, for example, whether the government intervened to promote environmental protection or rather to maximize agricultural and rural development interests given increasing European pressure for environmental conservation and infrastructure cost recovery. Although this speaks about the "why" of governmental/bureaucratic decisions and our concern is rather about the "how" of those decisions, it is difficult to separate both. An extension of the approach shall integrate both questions concerns.

Second, understanding the existence and nature of strategic interactions between local users is useful to diagnose problems and solutions; however, the strategic nature of the problem is not the only relevant piece of information. Historical contexts, and non-economic aspects such as identity and culture matter too (Van Riper et al. in press). Additionally, delimiting the group of local users is challenging. Local user groups were equated to farmers in most of the cases reviewed here. However there are potentially as many types of users as ecosystem services and groups that benefit from those services (Boyd and Banzhaf 2007). Indeed, a broad definition of "user" may make drawing the boundaries between "local" resource users and the larger public quite difficult. Finally, identifying the action situations that local users face is difficult. As illustrated in all cases, and also pointed in related research, local resource users' decisions are shaped by multiple action situations and clarifying how those situations are linked is an empirical question in itself (Lubell et al. 2010, Kimmich and Villamayor-Tomas 2017). Moreover, structures of incentives can be also constructed. As pointed out by Ostrom (1990) and also illustrated in the Greek case, the prisoner's dilemma can be also "fictional" to the extent that actors see themselves "imprisoned" in their inability to communicate or reach agreements. Last but not least, and as illustrated in the French case, users may move from one type of action situation to another as policies are implemented, which makes inferences about the relationship between instruments and behaviour particularly difficult.

Finally, a limitation of this study is the absence of counterfactuals. We are not including in this analysis cases of failed collective action given a government intervention. In other words, our analysis does not allow us to test hypotheses about whether some policy instruments are more appropriate than others to promote local collective action. The lack of appropriate counterfactuals, has indeed been pointed as a pervasive problem in collective action research (Agrawal 2003). Although the critique is legitimate, the identification of commonalities among 
"positive" cases is still a valid strategy. This is particularly the case when the goal is to identify patterns rather than to test them (see, for example, Ostrom 1990). As illustrated here, different instruments (and mechanisms) can contribute to local collective action and this diversity can be partially explained by the action situation addressed. Further, counterfactual analysis is not the only path to internal validity; process tracing and within case comparisons can also contribute to it (Steinberg, 2007). These strategies were indeed helpful to link policy interventions and default situations in our cases. As illustrated by the French case, the correlation between the phasing out of the policy intervention and collective action among farmers supports a causal association between the two, which can be further understood via our analytical approach.

\section{Conclusions}

While a number of policy studies have theorized about the different instruments governments can use to solve public and environmental problems, there is still rudimentary understanding about how they relate to local collective action. We have addressed this gap by exploring synergies between the IAD framework, collective action theory and policy instrument choice theory. In the proposed approach we build on the distinction between situations that involve cooperation or coordination dilemmas and those that involve conflict in the form of zero-sum or externality situations. We have then linked the possibility of promoting local collective action in those situations to certain policy instruments and their impact on different types of rules. We expected coordination dilemmas and conflict situations to align with instruments that reduce transaction costs and uncertainty (i.e., information and organizational instruments); and cooperation dilemmas to do so with interventions that change pay-offs and understandings (i.e., economic, command-and-control and information instruments). We did not have strong expectations about alignments between instruments and rules. To test the approach and our conjectures and explore rule linkages we leveraged data from four water management case studies in Europe where government has promoted collective action among local users to tackle a management problem.

As illustrated in the analysis, we found an alignment between prisoner's dilemma and conflict situations on the one hand, and economic and command-and-control instruments on the other. This supports the second of our conjectures. Alternatively, we found that organizational and informational instruments were not univocally associated to coordination situations, which goes against our first conjecture and highlights the importance of transaction costs across the board.

The analysis of rules is also revealing. Government intervention translated in both the creation of new rules as well as the modification of existing ones and affected most types of rules in all cases. This illustrates the complexity of understanding government impact at local levels. Also, rules that structure self-organization (i.e., to constitute local organizations and pave the way for collective decisions) revealed important but were not sufficient. Stakeholders still needed to buy into the new collective organization processes and abide by the decisions that emerged from them. Command-and-control instruments played an important role in both regards (i.e., to structure local self-organization and reduce uncertainty of local collective processes). Further research shall address more systematically the potential of command-and-control instruments vis a vis local collective action, also with an eye to existing literature about their deficits (Acheson 2006, Cox 2016). Based on our findings, we would expect that the effectiveness of this type of instruments increases when (1) they enforce constitutional-level rules (e.g., new organizational boundaries and positions that pave the way for self-organization among resource users); (2) when they contribute to the credibility/enforcement of rules that emerge from selforganization processes (previously promoted by the government or not); and/or (3) when they 
are implemented along with instruments that reduce the transaction costs and uncertainty associated to local collective action.

More generally, the analysis shows that looking at strategic interactions, policy instruments and collective action mechanisms can shed light on the degree of complexity of environmental problems and solutions. In two out of our four cases, problems involved the understanding of multiple action situations. In none of the cases the emergence of collective action resulted from a single policy instrument or mechanism. The lack of a large sample limits the ability to see clear associations between policy instruments and the situations that local users. Still, the approach does allow us to provide some reasoned insights about why we see collective action emerging given the implementation of certain policy instruments.

Overall, the framework draws the attention to different building blocks to better understand opportunities for the government to promote local collective action. The framework should therefore be taken as a heuristic to assess said opportunities rather than as a blueprint for policy recommendation. Further research shall expand the sample of cases. Also, the framework could be expanded by including other types of situations and that way assess other qualities of collective action settings, such as the time scale or the tangibility of the common good generated. Similarly, our compilation of collective action mechanisms may be incomplete; further work shall expand it within and beyond CPR and policy instrument choice theory.

\section{References}

Acheson, J. M. 2006. Institutional Failure in Resource Management. Annual Review of Anthropology 35:117-134.

Agrawal, A. 2001. Common Property Institutions and Sustainable Governance of Resources. World Development 29(10):1649-1672.

Agrawal, A. 2003. Sustainable Governance of Common Pool Resources: Context, Methods, and Politics. Annual Review of Anthropology 32(1):243-262.

Aligica, P. D. 2005. Institutional analysis and economic development policy: notes on the applied agenda of the Bloomington School. Journal of Economic Behavior \& Organization 57(2):159-165.

Anderies, J. M., M. A. Janssen, F. Bousquet, J.-C. Cardenas, D. Castillo, M.-C. Lopez, R. Tobias, B. Vollan, and A. Wutich. 2011. The challenge of understanding decisions in experimental studies of common pool resource governance. Ecological Economics 70(9):1571-1579.

Ansell, C., and A. Gash. 2008. Collaborative governance in theory and practice. Journal of Public Administration Research and Theory 18(4):543-571.

Anthony, D. L., and J. L. Campbell. 2011. States, social capital and cooperation: looking back on'Governing the Commons'. International Journal of the Commons 5(2):284-302.

Balliet, D. 2010. Communication and Cooperation in Social Dilemmas: A Meta-Analytic Review. Journal of Conflict Resolution 54(1):39-57.

Bates, R. H., A. Greif, M. Levi, J.-L. Rosenthal, and B. Weingast. 1998. Analytic narratives. Princeton University Press, Princeton, N.J.

Bemelmans-Videc, M.-L., R. C. Rist, and E. O. Vedung. 2011. Carrots, sticks, and sermons: Policy instruments and their evaluation. Transaction Publishers. 
Berkes, F. 2004. Rethinking Community-Based Conservation. Conservation Biology 18(3):621-630.

Bernard, P.-Y. 2004. Gestion concertée de l'eau en Lorraine. Quels enseignements tirer d'une opération locale Ferti-Mieux? Travaux et Innovations(11):1-4.

Boeuf, B., and O. Fritsch. 2016. Studying the implementation of the Water Framework Directive in Europe: a meta-analysis of 89 journal articles. Ecology and Society 21(2).

Bouma, J., and E. Ansink. 2013. The role of legitimacy perceptions in self-restricted resource use: A framed field experiment. Forest Policy and Economics 37:84-93.

Bowles, S. 2009. Microeconomics: behavior, institutions, and evolution. Princeton University Press.

Boyd, J., and S. Banzhaf. 2007. What are ecosystem services? The need for standardized environmental accounting units. Ecological Economics 63(2):616-626.

Bromley, D. W. 1991. Environment and economy: property rights and public policy. Basil Blackwell Ltd.

Cárdenas, J.-C., and E. Ostrom. 2004. What do people bring into the game? Experiments in the field about cooperation in the commons. Agricultural Systems 82(3):307-326.

Casajús Murillo, L., J. Subirats, and P. Arrojo Agudo. 2012. nuevos paradigmas en la gestión del agua en España. Crisis de gobernabilidad del agua en Aragón. Los conflictos de Yesa y Matarraña. Universitat Autònoma de Barcelona.

Celaya, N. 2006. La experiencia del Matarraña vista desde la Iniciativa Social de Mediación para los conflictos del agua en Aragón. Page Seminario sobre la información y la participación pública en la Directiva Marco del Agua en Navarra. Villalba.

Collier, D. 2011. Understanding Process Tracing. PS: Political Science \& Politics 44(04):823830.

Cox, M. 2016. The pathology of command and control: a formal synthesis. Ecology and Society 21(3).

Davies, B., K. Blackstock, K. Brown, and P. Shannon. 2004. Challenges in creating local agrienvironmental cooperation action amongst farmers and other stakeholders. The Macaulay Institute, Aberdeen.

Delmas, M., and A. Keller. 2005. Free riding in voluntary environmental programs: The case of the U.S. EPA WasteWise program. Policy Sciences 38(2-3):91-106.

Dimadama, Z., and D. Zikos. 2010. Social networks as Trojan horses to challenge the dominance of existing hierarchies: knowledge and learning in the water governance of Volos, Greece. Water Resources Management 24(14):3853-3870.

Driessen, P. P. J., C. Dieperink, F. Laerhoven, H. A. C. Runhaar, and W. J. V. Vermeulen. 2012. Towards a Conceptual Framework for The Study of Shifts in Modes of Environmental Governance - Experiences From The Netherlands. Environmental Policy and Governance 22(3):143-160.

Engel, S., S. Pagiola, and S. Wunder. 2008. Designing payments for environmental services in theory and practice: An overview of the issues. Ecological Economics 65(4):663-674.

Frey, U. J., S. Villamayor-Tomas, and I. Theesfeld. 2016. A continuum of governance regimes: A new perspective on co-management in irrigation systems. Environmental Science \& 


\section{Policy 66:73-81.}

Garces-Restrepo, C., D. Vermillion, and G. Muñoz. 2007. Irrigation management transfer: Worldwide efforts and results. Page FAO Water Reports. Fod and Agriculture Organization of the United Nations, Rome, Italy.

Goulder, L. H., and I. W. H. Parry. 2008. Instrument choice in environmental policy. Review of environmental economics and policy 2(2):152-174.

Grafton, R. Q. 2000. Governance of the Commons: A Role for the State? Land Economics:504517.

Gusfield, J. R. 1981. The culture of public problems : drinking-driving and the symbolic order. University of Chicago Press, Chicago.

Hajer, M., and D. Laws. 2010. Orderni through discourse. Pages 252-268 in M. Moran, M. Rein, and R. E. Goodin, editors. The Oxford handbook of public policy [electronic resource]. Oxford University Press.

Hardin, G. 1968. The Tragedy of the Commons. Science 162(5364):1243-1248.

Hood, C. 1986. The tools of government. Chatham. Chatham House Publishers, Jew Jersey.

Howlett, M. 2004. Beyond Good and Evil in Policy Implementation: Instrument Mixes, Implementation Styles, and Second Generation Theories of Policy Instrument Choice. Policy and Society 23(2):1-17.

Howlett, M. 2009. Governance modes, policy regimes and operational plans: A multi-level nested model of policy instrument choice and policy design. Policy Sciences 42(1):73-89.

Jordan, A., R. K. W. Wurzel, and A. Zito. 2005. The rise of 'new'policy instruments in comparative perspective: has governance eclipsed government? Political studies 53(3):477-496.

Jordan, A., R. K. W. Wurzel, and A. R. Zito. 2010.' New' Instruments of Environmental Governance : Patterns and Pathways of Change. Environmental Politics 12(July 2012):3741.

Kallis, G., N. Videira, P. Antunes, G. Pereira, C. L. Spash, H. Coccossis, S. C. Quintana, L. del Moral, D. Hatzilacou, G. Lobo, A. Mexa, P. Paneque, B. P. Mateos, and R. Santos. 2006. Participatory methods for water resources planning. Environment and Planning C: Government and Policy 24(2):215-234.

Kimmich, C. 2013. Linking action situations: Coordination, conflicts, and evolution in electricity provision for irrigation in Andhra Pradesh, India. Ecological Economics 90(0):150-158.

Kimmich, C., and S. Villamayor-Tomas. 2017. Assessing Action Situation Networks: A Configurational Perspective on Water and Energy Governance in Irrigation Systems. Water Economics and Policy:1850005.

Kiser, L. L., and E. Ostrom. 1982. The three worlds of action: A metatheoretical synthesis of institutional approaches. Pages 56-89 in M. D. McGinnis, editor. Polycentric Games and Institutions: Readings from the Workshop in Political Theory and Policy Analysis. University of Michigan Press, Ann Arbor.

Koontz, T. M., T. A. Steelman, J. Carmin, K. S. Korfmacher, C. Moseley, and C. W. Thomas. 2004. Collaborative environmental management: What roles for government? Resources for the Future, New York. 
Lascoumes, P., and P. Le Galès. 2007. Introduction: Understanding public policy through its instruments-From the nature of instruments to the sociology of public policy instrumentation. Governance 20(1):1-21.

Leach, W. D., and P. A. Sabatier. 2003. Are Trust and Social Capital the Keys to Success? Watershed Partnerships in California and Washington. Pages 233-258 in P. A. Sabatier, W. Focht, M. Lubell, Z. Trachtenberg, A. Vedlitz, and M. Matlock, editors. Swimming Upstream: Collaborative Approaches to Watershed Management. MIT press, Cambridge MA.

Lemos, M. C., and A. Agrawal. 2006. Environmental governance. Annu. Rev. Environ. Resour. 31:297-325.

de Lima, L. S., T. Krueger, and J. García-Marquez. 2017. Uncertainties in demonstrating environmental benefits of payments for ecosystem services. Ecosystem Services 27:139149.

Lopez-Gunn, E., and L. M. Cortina. 2006. Is self-regulation a myth? Case study on Spanish groundwater user associations and the role of higher-level authorities. Hydrogeology Journal 14(3):361-379.

Lopez, M. C., and S. Villamayor-Tomas. 2017. Understanding the black box of communication in a common-pool resource field experiment. Environmental Science and Policy 68:6979.

Lubell, M. 2003. Collaborative Institutions, Belief-Systems, and Perceived Policy Effectiveness. Political Research Quarterly 56(3):309-323.

Lubell, M., A. D. Henry, and M. McCoy. 2010. Collaborative institutions in an ecology of games. American Journal of Political Science(54):287-300.

Lubell, M., M. Schneider, J. T. Scholz, and M. Mete. 2002. Watershed Partnerships and the Emergence of Collective Action Institutions. American Journal of Political Science 46(1):148-163.

Lund-Thomsen, P., and K. Nadvi. 2010. Global value chains, local collective action and corporate social responsibility: a review of empirical evidence. Business Strategy and the Environment 19(1):1-13.

Mahoney, J. 2001. Review essay: Beyond correlational analysis: recent innovations in theory and method. Pages 575-593 Sociological forum. Springer.

Mansbridge, J. 2014. The role of the state in governing the commons. Environmental Science \& Policy 36:8-10.

Maxwell, J. W., T. P. Lyon, and S. C. Hackett. 2000. Self-Regulation and Social Welfare: The Political Economy of Corporate Environmentalism. The Journal of Law and Economics 43(2):583-618.

McGinnis, M. 2005. Costs and Challenges of Polycentric Governance. Page Workshop on Analyzing Problems of Polycentric Governance in the Growing EU. Humboldt-Universität zu Berlin. Berlin, Germany.

McGinnis, M. D. 2011a. An Introduction to IAD and the Language of the Ostrom Workshop: A Simple Guide to a Complex Framework. Policy Studies Journal 39(1):169-183.

McGinnis, M. D. 2011b. Networks of Adjacent Action Situations in Polycentric Governance. Policy Studies Journal 39(1):51-78. 
Mckenzie, D. M. 2000. Promoting Sustainable Behavior: An Introduction to Community-Based Social Marketing. Journal of Social Issues 56(3):543-554.

Meinzen Dick, R. 2007. Beyond panaceas in water institutions. Proceedings of the National Academy of Sciences 104(39):15200-15205.

Monge, C., and C. Presa. 2011. Condiciones necesarias para la puesta en marcha de un contrato de río en el Matarraña. Page VII Congreso Ibérico sobre Gestión y Planificación del Agua "Ríos Ibéricos.

Moran, E. F., M. C. Lopez, N. Moore, N. Müller, and D. W. Hyndman. 2018. Sustainable hydropower in the 21st century. Proceedings of the National Academy of Sciences of the United States of America 115(47):11891-11898.

Mueller, D. C. 1997. Perspectives on public choice: a handbook. Cambridge University Press.

Muradian, R. 2013. Payments for ecosystem services as incentives for collective action. Society \& Natural Resources 26(10):1155-1169.

Newig, J., and O. Fritsch. 2009. Environmental governance: participatory, multi-level - and effective? Environmental Policy and Governance 19(3):197-214.

North, D. C. 1988. Theorie des institutioneller Wandels: eine neue Sicht der Wirtschaftsgeschichte (Einheit der Gesellschaftswissenschaften 56). Tübingen.

OECD. 2013. Providing Agri-environmental Public Goods through Collective Action. OECD Publishing, Paris.

Ostrom, E. 1990. Governing the Commons: The Evolution of Institutions for Collective Action. Cambridge University Press, Cambridge, MA.

Ostrom, E. 1992. The rudiments of a theory of the origins, survival, and performance of common-property institutions. Pages 293-319 in D. W. Bromley, editor. Making the Commons Work: Theory Practice and Policy. ICS Press, CA: San Francisco.

Ostrom, E. 1999a. Institutional Rational Choice: An Assessment of the Institutional Analysis and Development Framework. Page in P. A. Sabatier, editor. Theories of the Policy Process. Westview Press, Boulder, CO.

Ostrom, E. 1999b. Coping with tragedies of the commons . Annual Review of Political Science 2(1):493.

Ostrom, E. 2007. Collective action theory. Page The Oxford handbook of comparative politics.

Ostrom, E. 2010. Analyzing collective action. Agricultural Economics 41:155-166.

Ostrom, E. 2011. Background on the Institutional Analysis and Development Framework. Policy Studies Journal 39(1):7-27.

Ostrom, E., and M. Cox. 2010. Moving beyond panaceas: a multi-tiered diagnostic approach for social-ecological analysis. Environmental Conservation 37(04):451-463.

Ostrom, E., R. Gardner, and J. Walker. 1994. Rules, Games and Common Pool Resources. Michigan University Press, Michigan.

Ostrom, E., and J. Walker. 1991. Communication in a Commons: Cooperation without External Enforcement. Page in T. R. Palfrey, editor. Laboratory Research in Political Economy. Michigan University Press, Michigan.

Papy, F., and A. Torre. 2002. Quelles organisations territoriales pour concilier production 
agricole et gestion des ressources naturelles? Etudes et Recherches sur les Systèmes Agraires et le Développement:151-169.

Pavitt, C. 2011. Communication, Performance, and Perceptions in Experimental Simulations of Resource Dilemmas.

Poteete, A. R., E. Ostrom, and M. Janssen. 2010. Working Together. Princeton University Press, Princeton, NY.

Richards, K. R. 2000. Framing Environmental Policy Instrument Choice. Duke Envtl. L. \& Pol'y F. 10(2).

Van Riper, C. J., A. Thiel, M. Penker, A. C. Braito, and J. M. Landon. (n.d.). Incorporating multi-level values into the social-ecological systems framework. In Ecology and Society.tle. Ecology \& Society.

Sabatier, P. A., W. Focht, M. Lubell, Z. Trachtenberg, A. Vedlitz, and M. Matlock. 2005. Collaborative approaches to waterhsed management. Page in P. A. Sabatier, W. Focht, M. Lubell, Z. Trachtenberg, A. Vedlitz, and M. Matlock, editors. Swimming Upstream: Collaborative approaches to Watershed Management. The MIT Press, Cambridge, MA.

Scharpf, F. W. 1997. Games Real Actors Play: Actor-centered Institutionalism In Policy Research. Westview Press, Boulder, CO.

Schelling, T. 1980. The Strategy of Conflict. Harvard University Press.

Schleyer, C. 2012. Institutioneller Wandel von Meliorationssystemen: eine vergleichende Studie in Ostdeutschland und Polen. Shaker.

Schneider, A., and H. Ingram. 1993. Social Construction of Target Populations: Implications for Politics and Policy. The American political science review 87(2):334-347.

Sikor, T., J. He, and G. Lestrelin. 2017. Property Rights Regimes and Natural Resources: A Conceptual Analysis Revisited. World Development 93:337-349.

Stavins, R. N. 2007. Environmental economics. National Bureau of Economic Research.

Villamayor-Tomas, S., M. Avagyan, M. Firlus, G. Helbing, and M. Kabakova. 2016. Hydropower vs. fisheries conservation: a test of institutional design principles for common-pool resource management in the lower Mekong basin social-ecological system. Ecology and Society 21(1).

Villamayor-Tomas, S., F. D. Fleischman, I. Perez Ibarra, A. Thiel, and F. van Laerhoven. 2014. From Sandoz to Salmon: Conceptualizing resource and institutional dynamics in the Rhine watershed through the SES framework. International Jounal of the Commons 8(2):361395.

Walls, M., and K. Palmer. 2001. Upstream pollution, downstream waste disposal, and the design of comprehensive environmental policies. Journal of Environmental Economics and Management 41(1):94-108.

Williamson, O. E. 1981. The Economics of Organization: The Transaction Cost Approach. American Journal of Sociology 87(3):548-577.

Zavalloni, M., M. Raggi, and D. Viaggi. 2016. Assessing Collective Measures in Rural Policy: The Effect of Minimum Participation Rules on the Distribution of Benefits from Irrigation Infrastructure. Sustainability 9(1):1.

Zikos, D. 2010. Community involvement in the implementation of the WFD in Greece. 
Zikos, D., and K. Hagedorn. 2017. Competition for Water Resources From the European Perspective. Competition for Water Resources: Experiences and Management Approaches in the US and Europe:19.

Zikos, D., and M. Roggero. 2013. The Patronage of Thirst: Exploring Institutional Fit on a Divided Cyprus. Ecology and Society 18(2):art25.

Zikos, D., A. H. Sorman, and M. Lau. 2015. Beyond water security: asecuritisation and identity in Cyprus. International Environmental Agreements: Politics, Law and Economics 15(3):309-326.

Zikos, D., and A. Thiel. 2013. Action research's potential to foster institutional change for urban water management. Water 5(2):356-378. 


\section{Appendix 1.a: Types of rules that affect action situations}

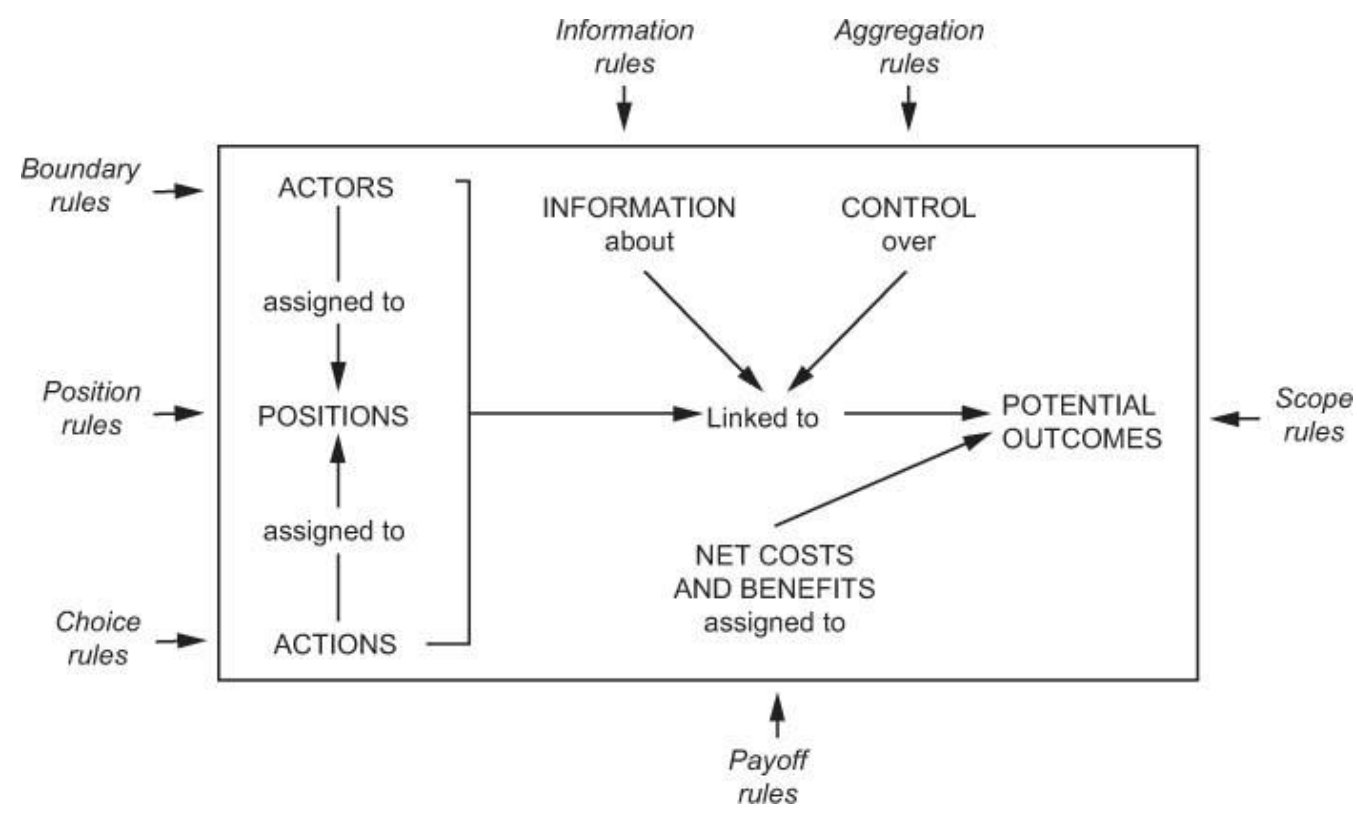

Source: Ostrom et al. (1994)

Appendix 1.b Operationalization of 7 types of rules vis collective use/management of local water resources

\begin{tabular}{|c|c|c|}
\hline Rule object & Definition of object & Question that the rule addresses \\
\hline Scope & $\begin{array}{l}\text { The range of policy issues local } \\
\text { users can address as a group }\end{array}$ & $\begin{array}{l}\text { What are the ensemble of local users } \\
\text { allowed, mandated or forbidden to do } \\
\text { collectively vis a vis water management? }\end{array}$ \\
\hline Boundary & $\begin{array}{l}\text { The separation between local users } \\
\text { who are part of a collective action } \\
\text { venture from those who are not }\end{array}$ & $\begin{array}{l}\text { Which local users are allowed/obliged to be } \\
\text { part of local collective action for water } \\
\text { management? }\end{array}$ \\
\hline Position & $\begin{array}{l}\text { Roles enacted/assigned to local } \\
\text { users who share a resource and/or } \\
\text { self-organize to manage it }\end{array}$ & $\begin{array}{l}\text { Which roles are assigned to users as such } \\
\text { and/or as participants in local collective } \\
\text { management? }\end{array}$ \\
\hline Choice & $\begin{array}{l}\text { Range of use and/or management } \\
\text { decisions local users can make } \\
\text { based on their roles }\end{array}$ & $\begin{array}{l}\text { Which tasks/decision capacities are assigned } \\
\text { to positions? }\end{array}$ \\
\hline Aggregation & $\begin{array}{l}\text { Collective decisions made by the } \\
\text { ensemble of local resource users }\end{array}$ & $\begin{array}{l}\text { How does the ensemble of water users make } \\
\text { water management decisions? }\end{array}$ \\
\hline Information & $\begin{array}{l}\text { Information about the conditions of } \\
\text { the resource, and use }\end{array}$ & $\begin{array}{l}\text { Which information is generated, managed } \\
\text { and shared among local water users? }\end{array}$ \\
\hline Pay-off & $\begin{array}{l}\text { Costs and benefits associated to the } \\
\text { use/management of the resource }\end{array}$ & $\begin{array}{l}\text { Which benefits and costs, rewards and } \\
\text { sanctions do local water users face when } \\
\text { using and/or collectively managing water? }\end{array}$ \\
\hline
\end{tabular}




\section{Appendix 2. Methods and sources of case studies}

Schraden, Germany: The analysis is based on a $\mathrm{Ph} . \mathrm{D}$. thesis that undertook a comparative case study of the Schraden, Germany and a second Polish case. In this paper we used the German case for illustrative purposes. The focus of the study was institutional change in drainage management in post-socialist contexts after the fall of the socialist German Democratic Republic. This obviously included a detailed description and analysis of the way a new legal and policy framework re-configured collective action around drainage management in the Schraden. Data sources of this analysis can be found in Schleyer 2012. They comprise twelve participatory workshops that were part of a large research project carried out in 2000, sixteen key informant interviews, half of which were carried out in 2000 and half of which were carried out in 2005, and an extensive review of documents of protocols of meetings of the drainage association and subject-specific newletters covering the area since the fifties. Interviews were transcribed and coded according to an analytical framework that captured institutional change in drainage management.

France: The core study used in the analysis of Ferti-Mieux operations in France is a master thesis (Verron, 2007). This study relies on data collected through 22 interviews with coordinators of Ferti-Mieux operations in 2007. Two technical papers were used to complement the analysis of the case. Bernard (2004) provides a synthesis of evaluation reports realized by agricultural organizations, focusing more particularly on Ferti-Mieux collective initiatives in the Lorraine region in the Rhin-Meuse water basin. Papy and Torre (2002) provides for a background on the development of the Ferti-Mieux program as well as an evaluation of their environmental impact at the national scale.

Greece: Background information on the Greek case is based on the articles by Dimadama and Zikos (2010), Zikos and Thiel 2013 and Zikos 2010 and build upon processes initated through the FP5 project "New Intermediary Services and the Transformation of Urban Water Supply and Wastewater Disposal Systems in Europe "(EVK1-CT-2002-00115). The work investigated how conventional hierarchies and dominant logics in Volos region in Greece, are challenged indirectly, in a "Trojan-horse" like way. The work, following a participatory action research methodology, examined the role of informal structures, and more specifically an informal social network set up by the researchers as a new form of governance in the framework of spatial development that has emerged in the shadow of an existing hierarchy.

Spain: the Matarraña case is based on reports and scientific publications issued by members of the NGO which designed and organized the Water Commission and the conflict resolution rules and procedures (Celaya 2006, Monge and Presa 2011). Data was obtained also from the media (the conflict acquired high public visibility) and ad hoc conversations the mentioned authors (Ignacio Celaya and Cristina Monge). A third source of data was the doctoral thesis of Lourdes Casajús Murillo (2012), which studies and compares the Matarraña conflict with a similar conflict (the Yesa conflict) and relies on a thorough review of the media, meeting minutes of relevant authorities (including the Water Commission), 38 interviews with stakeholders and authorities, and observant participation (Casajús Murillo et al. 2012). 


\section{Appendix 3: Changes in rules as affected by government intervention}

\section{Drainage management, Germany}

\begin{tabular}{|c|c|c|}
\hline Rules & Before government intervention (default situation) & After government intervention \\
\hline Position & No rules: positions defined by location within landscape & $\begin{array}{l}\text { Municipalities raise fees from land-owners and municipalities make landowners } \\
\text { responsible for complying with drainage management rules. Statutes of the association } \\
\text { assign different leadership positions within association }\end{array}$ \\
\hline Boundary & No rules & Municipalities and farmers are obligatory members of the water user association. \\
\hline Choice & No rules (no positions) & $\begin{array}{l}\text { Water users including famers and municipalities are provided with choices associated } \\
\text { with particular positions negotiated in the water user association, the Agrarumweltforum } \\
\text { and guidelines underpinning various streams of subsidies; municipalities are obliged to } \\
\text { charge farmers (landowners) for drainage association and monitor payment }\end{array}$ \\
\hline Aggregation & No rules (no collective choice) & $\begin{array}{l}\text { Municipalities represent farmers in deliberation and collective choice within } \\
\text { Agrarumweltforum and water user association. Drainage association represents } \\
\text { municipalities in higher scale negotiations on management and investment }\end{array}$ \\
\hline Information & No rules: information obtained on an individual, ad hoc basis & $\begin{array}{l}\text { Rules of drainage management association provide for coordination of activities of } \\
\text { farmers, municipalities and water managers. Rules are monitored by municipalities } \\
\text { making rule compliance more predictable that way reducing uncertainty. Information } \\
\text { sharing within water user association, association coordinates interventions also in } \\
\text { regard to activities by public water and environmental agency. Transaction costs of } \\
\text { bargaining are lowered that way. }\end{array}$ \\
\hline Payoff & $\begin{array}{l}\text { No rules: mismanagement of drainage creates costs for } \\
\text { everyone; actors bearing or benefitting from free-rider } \\
\text { behavior }\end{array}$ & $\begin{array}{l}\text { Municipalities and farmers as obligatory members that paid membership fees; } \\
\text { nonpayment of fees is punished by municipalities. Membership implies benefits of } \\
\text { information sharing, collective management and project funding from public authorities. } \\
\text { Agro-environmental subsidies offset costs of drainage decisions that go against farmers' } \\
\text { interests. Infrastructure maintenance subsidy program }\end{array}$ \\
\hline Scope & No rules: Individual drainage decisions are not constrained & $\begin{array}{l}\text { Establishment of "Kleine-Pulsnitz water association" with the mission to manage } \\
\text { drainage through the statutes of the water user association, higher level laws and its } \\
\text { collaboration with state agencies }\end{array}$ \\
\hline
\end{tabular}


Pollution abatement, France

\begin{tabular}{|l|l|l|}
\hline Rules & Before government intervention (default situation) & After government intervention \\
\hline Position & No rules & $\begin{array}{l}\text { Rules defining the role of actors in different positions (committee members, } \\
\text { coordinator, participating farmers) }\end{array}$ \\
\hline Boundary & No rules & $\begin{array}{l}\text { Rules defining the membership of committees in charge of the Ferti-Mieux } \\
\text { program and the eligibility of farmers to participate (to have land in a given water } \\
\text { catchment) }\end{array}$ \\
\hline Choice & No rules (no positions) & $\begin{array}{l}\text { Members of the local Ferti-Mieux operations are allowed to co-design the details } \\
\text { of nitrogen management plans, which are validated by local and national } \\
\text { committees involving government representatives. }\end{array}$ \\
\hline Aggregation & No rules (no collective choice) & Collective-choice rules for the definition of nitrogen management plans \\
\hline Payoff & No rules: scarce information about pollution practices and impact & $\begin{array}{l}\text { Information sharing and reporting procedures within local operations and from the } \\
\text { local to the national level of the program. }\end{array}$ \\
\hline Scope & $\begin{array}{l}\text { General regulatory framework for nitrogen control (Nitrate } \\
\text { Directive). Sanctions are difficult to implement due to difficulties } \\
\text { to trace pollution to its sources (diffuse pollution) }\end{array}$ & $\begin{array}{l}\text { The Ferti-Mieux label is a positive reward to effective implementation of collective } \\
\text { nitrogen management plan. } \\
\text { Regulatory threat increases costs of polluting and/or failure to self-organize }\end{array}$ \\
\hline
\end{tabular}

\section{Participatory planning, Greece}

Participatory planning, Greece
\begin{tabular}{|c|l|l|}
\hline Rules & \multicolumn{1}{|c|}{ Before government intervention (default situation) } & After government intervention \\
\hline Position & $\begin{array}{l}\text { Decision making positions held by government and selection of } \\
\text { stakeholders }\end{array}$ & $\begin{array}{l}\text { Stakeholders are part of the decision-making process in consulting role at regional } \\
\text { and national levels }\end{array}$ \\
\hline Boundary & $\begin{array}{l}\text { All stakeholders affected by water works and management plans } \\
\text { are outside the decision-making process }\end{array}$ & $\begin{array}{l}\text { Participation is optional; relevant stakeholders are welcome to participate. Many } \\
\text { spin-off networks between actors emerge and participation in water for a is sought }\end{array}$ \\
\hline Choice & $\begin{array}{l}\text { Rules enabling participation of regional and local authorities and } \\
\text { stakeholders in central government's decisions not implemented. }\end{array}$ & $\begin{array}{l}\text { Ultimate decision stays in central government but influential participation of } \\
\text { stakeholders at all levels of governance is established. }\end{array}$ \\
\hline Aggregation & Authoritative decisions at central level, lack of transparency. & $\begin{array}{l}\text { Communication forum and collective choice rules: Consensus-based decisions by } \\
\text { all affected stakeholders }\end{array}$ \\
\hline Information & $\begin{array}{l}\text { No rules: No information on any activities related to the water } \\
\text { framework directive or water works and decisions. }\end{array}$ & Institutionalized shared information practices, co-creation of new knowledge \\
\hline Payoff & $\begin{array}{l}\text { Benefits of those interested in water protection come at the cost of } \\
\text { those interested in water supply; communication among } \\
\text { stakeholders is costly (i.e., risky) for stakeholders due to strongly } \\
\text { hierarchical and inefficient water governance structure. }\end{array}$ & $\begin{array}{l}\text { Increased payoffs for all as costs of information radically decreased, transaction } \\
\text { costs decreased, win-win situations. }\end{array}$ \\
\hline Scope & $\begin{array}{l}\text { Only certain courses of action (e.g., enlargement of water supply } \\
\text { infrastructure vs. nature protection) are considered legitimate. }\end{array}$ & $\begin{array}{l}\text { Culture of communication and mechanisms to resolve disagreements facilitate the } \\
\text { legitimation of a broader scope of (middle ground) solutions to competition over } \\
\text { water resources. }\end{array}$ \\
\hline
\end{tabular}


Dam building conflict, Spain

\begin{tabular}{|c|c|c|}
\hline Rules & Before government intervention (default situation) & After government intervention \\
\hline Position & $\begin{array}{l}\text { Local communities affected by dams are outside the decision- } \\
\text { making process. Farmers are represented in River Basin } \\
\text { Organization and enjoy lobbying power. }\end{array}$ & $\begin{array}{l}\text { Water Commission: all stakeholders hold same position in decision making } \\
\text { process. Regional government and NGO facilitate self-organization process. } \\
\text { Central government witnesses and ratifies (ultimate decision stays with } \\
\text { Commission). }\end{array}$ \\
\hline Boundary & $\begin{array}{l}\text { Only central government entities have decision making authority in } \\
\text { the design of dam-building policy }\end{array}$ & Water Commission: all stakeholders are part of the decision-making process. \\
\hline Choice & $\begin{array}{l}\text { Farmers lobby the River Basin Organization. Farmers and local } \\
\text { communities can raise concerns over dam-building project. } \\
\text { Ultimate decision is to be made by officials from River Basin } \\
\text { Organization and Spanish Dept. of Public Works }\end{array}$ & Stakeholders can make alternative proposals and collegiately decide among them. \\
\hline Aggregation & River Basin Organization: voting-based decisions & $\begin{array}{l}\text { Water Commission: Consensus-based decisions. Stakeholders are assigned votes } \\
\text { depending on representativeness. }\end{array}$ \\
\hline Information & $\begin{array}{l}\text { Public information process follows decision about dam building } \\
\text { project. } \\
\text { Environmental Impact Assessment requires the collection and } \\
\text { dissemination of information about the project }\end{array}$ & $\begin{array}{l}\text { Water Commission: Shared information and bargaining protocols about different } \\
\text { dam-building projects. Stakeholder groups are required to elaborate memorandums } \\
\text { of their interests and share them with each other. }\end{array}$ \\
\hline Payoff & $\begin{array}{l}\text { Economic compensations to communities are insufficient as } \\
\text { compared to the benefits to farmers; dams are financed mostly via } \\
\text { taxes. } \\
\text { The risk of losing too much off via bargaining makes the high-risk, } \\
\text { high-gain strategy of confrontation appealing to both communities } \\
\text { and farmers. }\end{array}$ & $\begin{array}{l}\text { No additional formal rules. Informally, however: no agreement would justify } \\
\text { discretionary action by central government in one or the other direction. }\end{array}$ \\
\hline Scope & $\begin{array}{l}\text { No environmental limitations on original dam building project, and } \\
\text { no realistic alternatives }\end{array}$ & $\begin{array}{l}\text { The Water Commission has authority to decide whether the old project or any } \\
\text { alternative to it are viable socially and environmentally for implementation. }\end{array}$ \\
\hline
\end{tabular}

